\title{
Feed utilization and growth of Dorper wethers on Opuntia-based diets
}

\author{
O.B. Einkamerer ${ }^{\#}$, H.O. de Waal, W.J. Combrinck and M.D. Fair \\ Department of Animal, Wildlife and Grassland Sciences \\ P.O. Box 339, University of the Free State, Bloemfontein 9300, South Africa
}

\begin{abstract}
Incremental levels of sun-dried and coarsely ground cactus pear (Opuntia ficus-indica var. Algerian) cladodes were used to substitute part of the lucerne hay in balanced diets fed to Dorper wethers $(\mathrm{n}=28$; $33.90 \pm 2.98 \mathrm{~kg}$ ) during a trial period of 63 days. The three treatment diets (T0, T24 and T36) comprised respectively (air dry basis) 0, 240 and $360 \mathrm{~g} / \mathrm{kg}$ Opuntia; 660, 410 and $285 \mathrm{~g} / \mathrm{kg}$ lucerne hay; $300 \mathrm{~g} / \mathrm{kg}$ maize meal; 0,10 and $15 \mathrm{~g} / \mathrm{kg}$ feed grade urea; and $40 \mathrm{~g} / \mathrm{kg}$ molasses meal. Apparent DM digestibility coefficients increased significantly $(0.714,0.732$, and 0.756$)$ with Opuntia inclusion in diets. Feed dry matter (DM) intake $(1.368,1.345$ and $1.317 \mathrm{~kg} \mathrm{DM} /$ day) and average daily gain $(117.8,116.4$ and $95.6 \mathrm{~g} /$ day) decreased slightly as Opuntia inclusion increased. Similar to previous studies the ingestion of Opuntia caused the production of wet faeces by the wethers. It was concluded that adequate nutrients were provided by these diets for maintenance and a moderate level of production in the Dorper wethers.
\end{abstract}

Keywords: Cactus pear, digestibility, feed intake, live weight gain, sheep, sun-dried

${ }^{\#}$ Corresponding author. E-mail: Einkamererob.sci@ufs.ac.za

\section{Introduction}

Cactus pears (Opuntia spp.) are used as livestock feed during the frequent periods of drought or food shortages in many arid and semi-arid regions (De Waal et al., 2006). These plants are drought resistant and produce high yields of biomass (Zeeman, 2005; De Waal et al., 2006). Opuntia is an important livestock feed in areas where few other crops can be produced (Reynolds \& Arias, 2001) and is particularly attractive because of its efficiency of using water to produce dry matter (Tegegne, 2001). In terms of available land and water, about 3 to 4 ha of spineless cactus can be planted for each ha of lucerne (De Kock, 1980).

The spineless cactus pear (Opuntia ficus-indica) fruit industry in South Africa has increased in recent years (Zeeman, 2005; De Waal et al., 2007). Large quantities of fruit are exported and thus large quantities of fresh cladodes also become available when the plants are pruned to improve fruit production and quality (Zeeman, 2005; De Waal et al., 2007). This creates the prospect of utilizing the large quantities of plant material that are produced annually as a feed source for livestock (De Waal et al., 2007).

In a previous study, Zeeman (2005) substituted lucerne hay in diets for Dorper wethers with up to 36\% sun-dried and coarsely ground Opuntia cladodes and recorded no apparent detrimental effects over a relatively short trial period. However, similar to other studies, inclusion of Opuntia cladodes caused the production of wet faeces by the sheep (De Waal et al., 2006; 2007). The aim of this study was to determine whether two treatment diets with incremental levels of sun-dried and coarsely ground Opuntia cladodes substituting lucerne hay will have the same capacity as the control diet to promote growth in young animals. It was important to establish if feed intake, diet digestibility and especially the performance of young Dorper wethers were affected negatively when these diets are fed over a period of several weeks.

\section{Materials and Methods}

The Opuntia ficus-indica var. Algerian cladodes used in this study were produced during the growing seasons of 2004/5 and 2005/6 and pruned from the plants in May 2006 on the farm Waterkloof, $20 \mathrm{~km}$ West of Bloemfontein in the Free State Province, South Africa. The Opuntia cladodes were cut lengthwise by hand with a single-machete (mounted on a flat wooden surface) into strips of approximately 15 to $25 \mathrm{~mm}$ and dried in direct sunlight on corrugated roof sheeting. After about 6 to 10 days the Opuntia cladode strips were considered sufficiently dried (about 700 to $850 \mathrm{~g} \mathrm{DM} / \mathrm{kg}$ ) to be collected and ground in a hammer mill to pass through a $20 \mathrm{~mm}$ sieve. Three treatment diets (T0, T24, and T36) were formulated to include 
incremental inclusion levels of 0,240 , and $360 \mathrm{~g} / \mathrm{kg}$ sun-dried and coarsely ground Opuntia cladodes as partial substitution of coarsely ground lucerne hay (Table 1 ).

Table 1 Air-dry composition of treatment diets with incremental inclusion levels of sun-dried and coarsely ground Opuntia cladodes

\begin{tabular}{lccc}
\hline Feed ingredients (kg) & \multicolumn{3}{c}{ Treatment diets $^{*}$} \\
\cline { 2 - 4 } & $\mathrm{T} 0$ & $\mathrm{~T} 24$ & $\mathrm{~T} 36$ \\
\hline Coarsely ground Opuntia cladodes & 0 & 240 & 360 \\
Coarsely ground lucerne hay & 660 & 410 & 285 \\
Yellow maize meal & 300 & 300 & 300 \\
Feed grade urea & 0 & 10 & 15 \\
Molasses meal (Calori 3000) & 40 & 40 & 40
\end{tabular}

"Inclusion levels of coarsely ground Opuntia cladodes: T0 - 0\%; T24 - 24\%; T36 - 36\%

Lucerne hay was ground through the same $20 \mathrm{~mm}$ sieve as the cladodes. Yellow maize meal, molasses meal (Calori 3000) and feed grade urea were included in the physical form in which these feeds are commercially available (Table 1). As the Opuntia cladodes were incrementally increased in the experimental diets, lucerne hay was decreased (Table 1). The crude protein (CP) content of the diets was balanced to be iso-nitrogenous by the inclusion of feed grade urea in the two diets that contained Opuntia cladodes, because Opuntia contains less CP than lucerne hay (77 compared to $184 \mathrm{~g} \mathrm{CP} / \mathrm{kg} \mathrm{DM}$ ).

For a period of nine weeks 28 young Dorper wethers $(33.9 \pm 2.98 \mathrm{~kg})$ were used in the trial that simulated conditions in a feedlot. Prior to being subjected to the treatments, the wethers were treated for internal parasites and vaccinated for pulpy kidney. Treatments were replicated due to limited space in the metabolism cages using a fully randomized block design, with block A starting one week prior to that of block B. Wethers were randomly allocated on average weight within each block between the three treatments (block A: $\mathrm{n}=4,5$ and 5 for treatments T0, T24 and T36, respectively; block B: $\mathrm{n}=5,4$ and 5 for treatments T0, T24 and T36, respectively). Wethers were housed in an open-sided roofed shed in small pens. The amount of feed offered and refused by the wethers in the different treatment groups was measured in 48-hour cycles, starting every day at noon. The food allocated for the next cycle was then calculated as the feed consumed times a factor of 1.15, as explained in detail by Einkamerer (2008).

At the end of the trial apparent digestibility of the treatment diets was determined by housing the wethers individually in metabolism cages for a period of one week. The metabolism cages are designed to separate and collect the faeces and urine of male sheep with a minimum loss (De Waal, 1979). While in the cages, the wethers were also offered food at a $15 \%$ refusal level of intake. However, feed allowance was calculated on a daily basis by using a 3-day moving average of feed intake of the preceding three days. During the trial the wethers were fed twice daily (12:30 and 08:00) and weighed weekly.

Representative samples (treatment diets, feed refused, and faeces) were collected for each wether and dried in a force draught oven at $100{ }^{\circ} \mathrm{C}$ for at least 16 hours. After thorough mixing, these samples were ground to pass through a $1 \mathrm{~mm}$ sieve and stored in plastic jars with airtight screw tops pending chemical analyses. A composite feed sample from each treatment diet was collected on a daily basis. The DM, organic matter (OM), ash, ether extracts (EE) and gross energy (GE) of samples were determined according to the procedures described by the AOAC (2000). The CP was determined with a Leco Nitrogen analyzer (Leco, 2001). A factor of 6.25 was used to convert the nitrogen $(\mathrm{N})$ content of the samples to CP content. Aciddetergent fibre (ADF) and neutral-detergent fibre (NDF) were determined according to the procedures described by Goering and Van Soest (1970) and Robertson \& Van Soest (1981). Sulphite and $\alpha$-amylase were not used as reagents during NDF determination.

The data of the block model was analyzed and tested for significant differences using the PROC ANOVA procedures of the SAS programme (SAS, 1999). When significant differences were found ( $P$ $<0.05$ ), further multiple comparisons using Tukey's higher studentized range (HSD) test were used to identify these differences. 


\section{Results and Discussion}

The OM, ADF, NDF, and GE content of the treatment diets decreased as the inclusion level of Opuntia cladodes increased (Table 2) and is ascribed to the lower OM, ADF, NDF, and GE content of Opuntia cladodes compared to lucerne hay. These results correspond with the findings of Zeeman (2005). The CP content also decreased as Opuntia inclusion increased incrementally as partial substitution of lucerne hay (Table 2) but was corrected by including small quantities of feed grade urea (Table 1). The treatment diets used in this study corresponded to three of the four diets used in the study by Zeeman (2005). The control diet T0 was formulated as a basal diet to ensure moderate growth of sheep. The same objective was set in formulating treatment diets T24 and T36 by partially substituting the coarsely ground lucerne with Opuntia and adding small quantities of feed grade urea (Table 1).

Table 2 Chemical composition of the three treatment diets with incremental inclusion levels of sun-dried and coarsely ground Opuntia cladodes

\begin{tabular}{lccc}
\hline \multirow{2}{*}{ Chemical constituents } & \multicolumn{3}{c}{ Treatment diets $^{*}$} \\
\cline { 2 - 4 } & & T0 & T36 \\
\hline Dry matter (g DM/kg) & 913 & 905 & 902 \\
Organic matter (g OM/kg DM) & 900 & 879 & 862 \\
Crude protein (g CP/kg DM) & 171 & 177 & 177 \\
Ether extract (g EE/kg DM) & 24 & 24 & 22 \\
Acid-detergent fibre (g ADF/kg DM) & 214 & 178 & 159 \\
Neutral-detergent fibre (g NDF/kg DM) & 413 & 363 & 313 \\
Gross energy (MJ/kg DM) & 17.3 & 16.7 & 15.5
\end{tabular}

*Inclusion levels of sun-dried and coarsely ground Opuntia cladodes: T0 - 0\%; T24 - 24\%; T36-36\%.

The average daily gain (ADG) of the wethers tended to decrease $(\mathrm{P}>0.05)$ (Table 3). Atti et al. (2006) found differences in the performance of male goat kids because the energy and fibre content of the treatment diets differed as a result of Opuntia inclusion. Nutrient deficiencies may be overcome when Opuntia-based diets are supplemented with protein and energy sources (Ben Salem et al., 2005). Thus, the body weight gains (Table 3) of the wethers were moderate and acceptable for these diets and could in part be ascribed to the levels of maize meal and urea (Table 1) included in the diets.

Table 3 Mean ( \pm s.e.) daily gain of Dorper wethers, dry matter (DM) and organic matter (OM) intake, apparent digestible DM and OM intake, as well as the apparent digestibility coefficients of three treatment diets with incremental inclusion levels of sun-dried and coarsely ground Opuntia cladodes

\begin{tabular}{lccccc}
\hline & \multicolumn{3}{c}{ Treatment diets $^{*}$} & P & CV $(\%)$ \\
\cline { 2 - 3 } & T0 & T24 & T36 & \\
Average daily gain (g/day) & $118 \pm 13.7$ & $116 \pm 15.6$ & $96 \pm 7.9$ & 0.3219 & 34.552 \\
DM intake (g/day) & $1368 \pm 69$ & $1345 \pm 46$ & $1317 \pm 61$ & 0.9039 & 13.858 \\
Digestible DM intake (g/day) & $977 \pm 51$ & $983 \pm 29$ & $995 \pm 44$ & 0.9414 & 13.421 \\
OM intake (g/day) & $1235 \pm 62$ & $1198 \pm 41$ & $1152 \pm 52$ & 0.7405 & 13.704 \\
Digestible OM intake (g/day) & $907 \pm 48$ & $905 \pm 28$ & $902 \pm 40$ & 0.9934 & 13.502 \\
DM digestibility coefficients & $0.714^{\mathrm{a}} \pm 0.004$ & $0.732^{\mathrm{a}} \pm 0.007$ & $0.756^{\mathrm{b}} \pm 0.004$ & $<0.0001$ & 2.055 \\
OM digestibility coefficients & $0.734^{\mathrm{a}} \pm 0.005$ & $0.757^{\mathrm{b}} \pm 0.006$ & $0.783^{\mathrm{c}} \pm 0.003$ & $<0.0001$ & 1.878 \\
\hline
\end{tabular}

${ }_{\mathrm{a}, \mathrm{b}}$ Means in the same row followed by different superscripts differ significantly $(\mathrm{P}<0.05)$

*Inclusion levels of sun-dried and coarsely ground Opuntia cladodes: T0 - 0\%; T24 - 24\%; T36 - 36\% 
No significant differences $(\mathrm{P}>0.05)$ were observed between the $\mathrm{DM}$ and $\mathrm{OM}$ intake of the wethers (Table 3). This is in agreement with the results reported by Zeeman (2005). The apparent DM and OM digestibility increased $(\mathrm{P}<0.05)$ with Opuntia inclusion (Table 3 ). This could explain why no effect on ADG was observed between the treatments. Zeeman (2005) also reported increases in apparent digestibility coefficients and ascribed it to the fact that Opuntia cladodes contain high levels of easily digestible carbohydrates (Ben Salem et al., 1996; 2004).

\section{Conclusions}

Dietary treatment had no effect $(\mathrm{P}>0.05)$ on feed intake of young Dorper wethers subjected to diets with sun-dried Opuntia cladodes included at $24 \%$ and $36 \%$.

The study by Zeeman (2005) concluded that Opuntia-based diets had no apparent negative effects on the growth of similar young Dorper wethers. However, the trial period of 19 days used by Zeeman (2005) was too short to draw definitive conclusions in this regard. Having been subjected in the current study to Opuntia-based diets for a longer period of nine weeks only tended to decrease $(\mathrm{P}>0.05)$ live weight gain at the highest level of inclusion (diet T36). Therefore, it can be concluded that sun-dried and coarsely ground Opuntia did not affect animal performance negatively at the inclusion levels used in this trial.

The results of the study suggest that Opuntia cladodes can be utilised as a partial replacement for lucerne hay in ruminant diets. It is recommended that the focus should now be on the formulation of Opuntia-based production diets with a high energy content to be used in feedlots. Supplementing additional protein, and energy feed sources would likely improve animal performance.

\section{References}

AOAC, 2000. Official Methods of Analysis of AOAC International. Volume 1. 17 $7^{\text {th }}$ ed. Ed. Horwitz, W., AOAC International ${ }^{\circledR}$.

Atti, N., Mahouachi, M. \& Rouissi, H., 2006. The effect of spineless cactus (Opuntia ficus-indica f. intermis) supplementation on growth, carcass, meat quality and fatty acid composition of male goat kids. Meat Sci. 73, 229-235.

Ben Salem, H., Nefzaoui, A., Abdouli, H. \& Ørskov, E.R., 1996. Effect of increasing level of spineless cactus (Opuntia ficus-indica var. inermis) on intake and digestion by sheep given straw-based diets. Anim. Sci. 62, 293-299.

Ben Salem, H., Nefzaoui, A. \& Ben Salem, L., 2004. Spineless cactus (Opuntia ficus-indica f. intermis) and oldman saltbush (Atriplex nummularia) as alternative supplements for growing Barbarine lambs given straw-based diets. Small Rumin. Res. 51, 65-73.

Ben Salem, H., Abdouli, H., Nefzaoui, A., El-Mastouri, A. \& Ben Salem, L., 2005. Nutritive value, behaviour, and growth of Barbarine lambs fed on oldman saltbush (Atriplex nummularia L.) and supplemented or not with barley grains or spineless cactus (Opuntia ficus-indica f. intermis) pads. Small Rumin. Res. 59, 229-237.

De Kock, G.C., 1980. Drought resistant fodder shrub crops in South Africa. In: Browse in Africa. The current state of knowledge. Ed. Le Houerou. International Livestock Centre for Africa. Addis Ababa, Ethiopia, 399-408.

De Waal, H.O., 1979. Die voedingswaarde van veldweiding van die sentrale Oranje-Vrystaat vir skape met spesiale verwysing na die rol van proteïen- en fosfaataanvullings. M.Sc. thesis. University of Stellenbosch.

De Waal, H.O., Fouché, H. \& Potgieter, J., 2007. Turksvye as voerbron vir herkouers. Opuntia - the Cinderella feed source? Bonsmara SA 2007, pp. 48-53.

De Waal, H.O., Zeeman, D.C. \& Combrinck, W.J., 2006. Wet faeces produced by sheep fed dried spineless cactus pear cladodes in balanced diets. S. Afr. J. Anim. Sci. 36, 10-13.

Einkamerer, O.B., 2008. Animal performance and utilization of Opuntia-based diets by sheep. M.Sc. Agric. thesis. University of the Free State, Bloemfontein, South Africa.

Goering, H.K. \& Van Soest, P.J., 1970. Forage fibre analysis. U.S.D.A. Agricultural Handbook, No. 379.

Leco, 2001. FP-528 Protein/Nitrogen Determinator. FP-528 Instruction Manual, Version 1.2. Leco® Corporation. 
Reynolds, S.G. \& Arias, E., 2001. Introduction. In: Cactus (Opuntia spp.) as forage. Eds Mondragón-Jacobo, C. \& Pérez-González, S. FAO Plant Production and Protection Paper 169. Food and Agriculture Organization of the United Nations, Rome. pp. 1-4.

Robertson, J.B. \& Van Soest, P.J., 1981. The detergent system of analysis and its application to human foods. In: The analysis of dietary fibre. Eds. James, W.P.T. \& Theander, O. Dekker, New York.

SAS, 1999. SAS ${ }^{\circledR}$ User's Guide. Version 6.12. SAS Institute Inc., Cary, N.C., USA.

Tegegne, F., 2001. Nutritional value of Opuntia ficus-indica as a ruminant feed in Ethiopia. In: Cactus (Opuntia spp.) as forage. Eds Mondragón-Jacobo, C. \& Pérez-González, S., FAO Plant Production and Protection Paper 169. Food and Agriculture Organization of the United Nations, Rome. pp. 91-99.

Zeeman, D.Z., 2005. Evaluation of sun-dried Opuntia ficus-indica var. Algerian cladodes in sheep diets. M.Sc. Agric. thesis. University of the Free State, Bloemfontein. 